\title{
Pembuatan Sel Surya Film Tipis dengan DC Magnetron Sputtering
}

\author{
Desty Anggita Tunggadewi ${ }^{1}$, Fitria Hidayanti ${ }^{1}$ \\ ${ }^{1}$ Program Studi Teknik Fisika, Fakultas Teknik dan Sains, Universitas Nasional \\ Korespondensi: dtunggadewi@yahoo.co.id
}

\begin{abstract}
ABSTRAK. Divais photovoltaic, atau yang umum disebut modul sel surya, menggunakan material semikonduktor untuk mengubah cahaya matahari secara langsung menjadi listrik. Semakin meningkatnya permintaan akan sumber energi terbarukan, maka pembuatan sel surya menjadi sangat penting. Pembuatan sel surya dengan DC Magneton Sputtering mampu menghasilkan performansi yang bagus. Lapisan tipis sel surya dibuat dari sambungan $\mathrm{p}-\mathrm{n}$ silikon dengan kombinasi multilayer Ag / SiB / SiP dan dideposisi oleh DC Magnetron Sputtering secara bertahap. Deposisi layer SiB dan SiP dengan memperhatikan parameter tekanan chamber sebesar 6 x 10-8 mbar, tekanan gas Argon 2 x 10-2 mbar, dan waktu deposisi SiB and SiP selama 16 menit dan 10 menit. Arus dan tegangan dari lapisan tipis sel surya yang telah difabrikasi, selanjutnya diuji dengan rangkaian seri dan paralel, kemudian dianalisis menggunakan program Logger Pro 3.8. Hasil kurva tampilan program sesuai dengan kurva karakteristik dioda. Efisiensi untuk sel surya tanpa kombinasi rangkaian adalah sebesar $6.02 \%$, dengan rangkaian seri sebesar $11.929 \%$ dan $8.737 \%$ untuk rangkaian paralel.
\end{abstract}

Kata kunci: solar cell, thin film, dc magnetron sputtering, efficiency solar cel.

\section{PENDAHULUAN}

Energi merupakan faktor yang sangat diperlukan untuk pertumbuhan Negara dan pembangunan ekonomi. Persedian energi fosil yang digunakan untuk energi listrik memiliki cadangan yang terbatas. Ketergantungan Indonesia pada energi fosil membuat produksi minyak bumi dalam negeri menurus drastis sejak tahun 2001. Keadaan ini didorong oleh kebutuhan yang terus naik dan tumbuhnya sektor industri di Indonesia. Ketergantungan energi fosil masih didominasi oleh kebutuhan minyak yang mencapai $41,8 \%$, batu bara $29 \%$ dan gas $23 \%$. Kebutuhan energi yang besar ini tidak bisa ditopang oleh cadangan energi Indonesia yang semakin menipis. Cadangan minyak di Indonesia hanya cukup untuk 23 tahun lagi, cadangan gas cukup untuk 50 tahun lagi dan cadangan batu bara cukup untuk 80 tahun lagi [1].

Melihat kondisi di Indonesia dimana kebutuhan listrik semakin meningkat maka perlu dikembangkan potensi energi baru dan terbarukan. Potensi energi terbarukan yang dapat dikembangkan di Indonesia yaitu angin, air terjun, panas bumi, pasang surut air laut (tidal), biomassa dan radiasi matahari (solar). Pemanfaatan radiasi matahari di Indonesia sangat sesuai karena Indonesia terdiri atas 2 (dua) musim yaitu musim kemaran dan penghujan dimana hampir 9 bulan dalam setahun Indonesia berada dalam musim kemarau. Lama Penyinaran Matahari di Indonesia berkisar antara 5-8 jam perhari.

Pembuatan sel surya sangat memungkinkan dengan adanya peralatan seperti DC Magnetron Sputtering. Instrumen ini digunakan untuk pembuatan lapisan tipis pada substrat kaca. Film tipis yang dihasilkan dari bahan semikonduktor, Silikon yang didop dengan Fospor dan Boron akan menghasilkan $p-n$ junction untuk berfungsi untuk menghasilkan aliran electron dari semikonduktor tipe $\mathrm{n}$ menuju hole pada semikonduktor tipe $\mathrm{p}$. aliran electron inilah yang menghasilkan arus listrik [2-4].

Penelitian ini bertujuan untuk menghasilkan sel surya menggunakan DC Magnetron Sputtering. Sel surya yang dihasilkan dirangkai secara seri dan paralel untuk meningkatkan arus yang diperoleh. Semakin banyak sel surya yang dihasilkan, arus yang dihasilkan pun akan semakin meningkat [5]. 


\section{METODE PENELITIAN}

Penelitian ini merancang pembuatan sel surya dengan DC Magnetron Sputtering dan karakterisasi sel surya sesuai dengan diagram alir pada gambar 1.

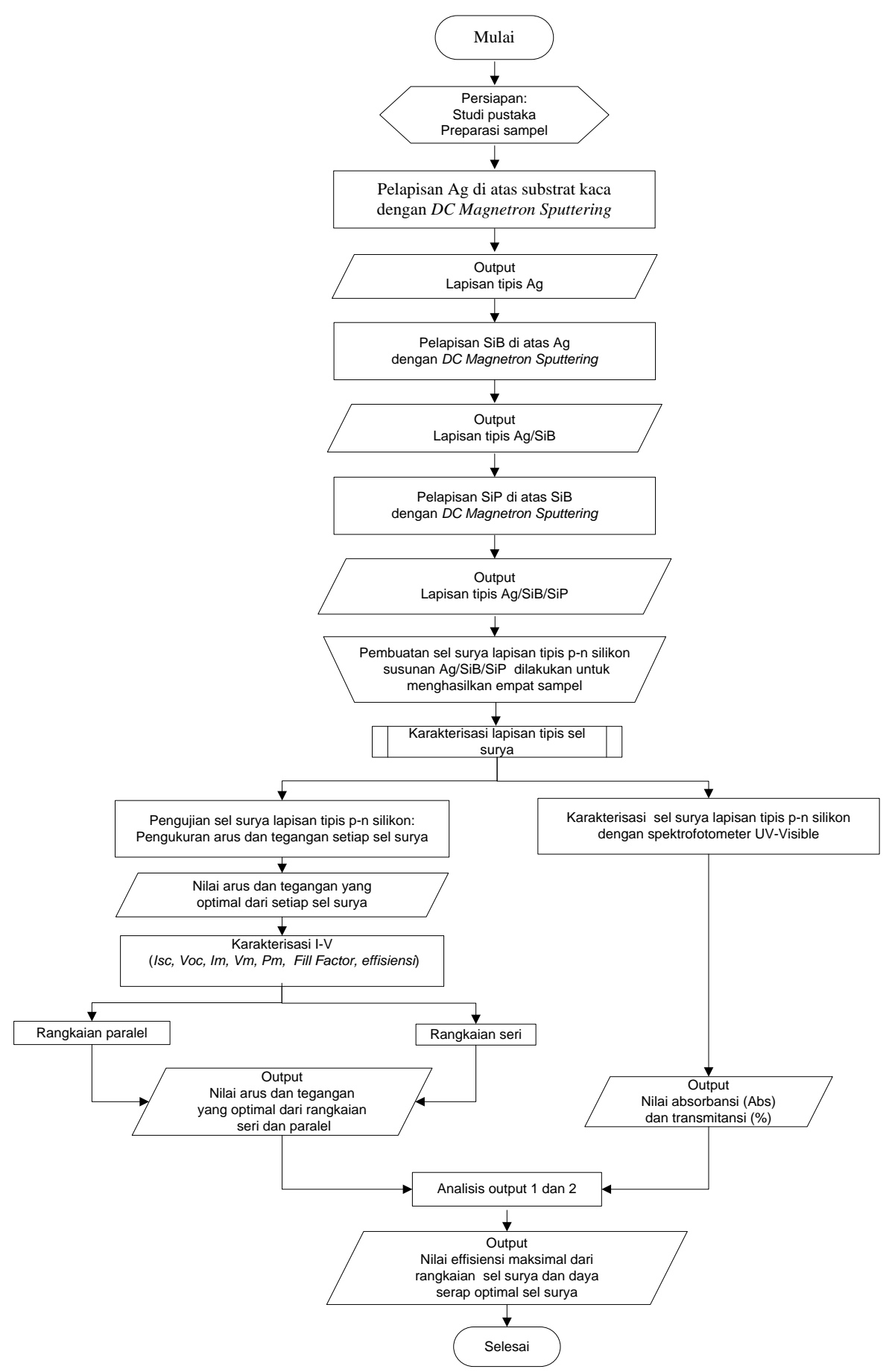

GAMBAR 1. Diagram Alir Penelitian

Sel surya dirangkai secara seri dan paralel untuk meningkatkan arus yang dihasilkan. Dalam penelitian ini, bahan yang digunakan sebagai semikonduktor adalah Silikon ( $\mathrm{Si}$ ) yang didop dengan Fospor (P) dan Boron (B). Bahan lainnya yaitu Perak (Ag) digunakan sebagai pengumpul (collector) sinar matahari. DC Magnetron Sputtering (Gambar 2) digunakan dalam pembuatan film tipis sel surya karena menghasilkan lapisan yang seragam (homogen) [1], [7-9]. 
DC Magnetron Sputtering merupakan proses deposisi uap plasma atau Plasma Vapor Deposition (PVD). Untuk mendapatkan film tipis yang baik diperlukan waktu 10 menit untuk pelapisan $\mathrm{Ag}$ dan waktu 16 menit untuk pelapisan SiP dan SiB. Dalam DC Magnetron Sputtering, diperlukan bahan berupa gas Argon. Gas Argon dipilih karena merupakan gas mulia yang tidak bereaksi dengan bahan pelapis dan berfungsi membawa atom bahan pelapis (target) dari katoda menuju anoda. Argon dalam proses ini bermuatan positif. Argon sebagai gas plasma akan dipercepat dengan beda potensial sekitar ratusan hingga ribuan $\mathrm{eV}$ dan menumbuk elektroda negatif atau katoda. Akibatnya, atom target akan lepas dari katoda menuju katoda. Deposisi dengan DC magnetron Sputtering menggunakan prinsip medan magnet tertutup untuk mengarahkan atom target bergerak dari katoda menuju anoda. Pada anoda, atom target akan terdeposisi terdeposisi membentuk film tipis sel surya $\mathrm{Ag} / \mathrm{SiP} / \mathrm{SiB}$ [10-11].

Karakterisasi sel surya dilakukan dengan multimeter untuk mendapatkan data arus dan tegangan. Data yang diperoleh kemudian diolah dengan Software Logger Pro 3.8 untuk mendapatkan nilai efisiensi sel surya. Penelitian ini dilakukan menggunakan DC Magnetron Sputtering di Batan. Data yang diperoleh berupa arus, tegangan, dan efisisensi sel surya.

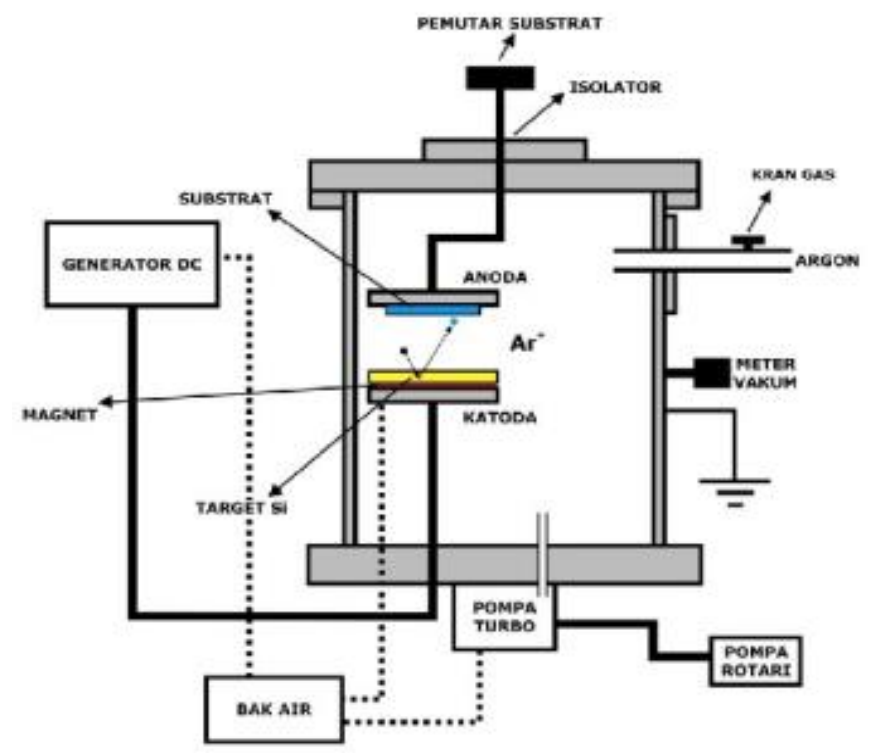

GAMBAR 2. Skema Teknik DC Magnetron Sputtering

\section{HASIL DAN PEMBAHASAN}

Sel surya lapisan tipis p-n silikon susunan $\mathrm{Ag} / \mathrm{SiB} / \mathrm{SiP}$ telah dibuat dengan metode $\mathrm{DC}$ Magnetron Sputtering dengan ketebalan lapisan dalam orde mikro meter. Metode DC Magnetron Sputtering merupakan pengembangan dari metode RF Sputtering, yaitu dengan penambahan sistem magnet dalam konstruksi target serta menggunakan generator DC. Pemasangan sistem magnet ini menyebabkan medan listrik yang terjadi antara kutub katoda dan anoda semakin besar.

Lapisan tipis yang dibuat merupakan lapisan sambungan semikonduktor tipe-p ( $\mathrm{SiB}$ ) dan semikonduktor tipe-n (SiP) yang dideposisikan di atas substrat kaca berukuran $30 \mathrm{~mm}$ x 25 $\mathrm{mm}$. Kualitas hasil deposisi/penumbuhan lapisan tipis ditentukan oleh parameter konsentrasi dopping, daya generator, tekanan gas sputter, kevakuman chamber dan waktu deposisi. Pada penelitian ini menggunakan parameter tekanan tanpa gas vakum) $10^{-6}$ mbar, dengan tingkat vakum tersebut diperoleh hasil deposisi dengan tingkat impurity yang rendah. Gas argon dengan tekanan $2 \times 10^{-2}$ mbar dialirkan ke dalam tabung sputtering kemudian terionisasi dan terbentuk plasma. Gas yang terionisasi dipercepat oleh medan listrik serta menghasilkan elektron dan ion-ion positif. Ion-ion positif akan tertarik ke katoda dan menembaki permukaan target dengan energi yang cukup tinggi sehingga atom-atom target terlepas ke 
segala arah termasuk ke arah substrat. Adanya medan magnet menyebabkan proses pendeposisian material target lebih optimal karena atom-atom target yang terpental akan terkonsentrasi ke substrat oleh gaya magnet pada katoda. Tegangan yang digunakan dari generator DC adalah 300-700 $\mathrm{V}$ dan arus 30-80 mA.

Pengukuran arus dan tegangan keluaran sel surya dilakukan dibawah pencahayaan sinar matahari dengan daya maksimum $480 \mathrm{~mW} / \mathrm{cm}^{2}$. Hasil pengukuran yang dilakukan selama tiga hari berturut-turut diperoleh nilai arus dan tegangan dari sel surya tunggal seperti ditunjukkan pada tabel 1. Pengukuran sel surya tunggal menghasilkan nilai tegangan maksimum $343 \mathrm{mV}$ untuk sel surya 3, dan nilai tegangan minimum $225 \mathrm{mV}$ untuk sel surya 4. Sedangkan hasil pengukuran arus diperoleh nilai arus maksimum $0,02 \mu \mathrm{A}$ untuk semua sel surya, dan nilai arus minimum $0,01 \mu \mathrm{A}$ untuk sel surya 4 .

TABEL 1. Hasil Pengukuran Arus dan Tegangan Sel Surya Tunggal

\begin{tabular}{|c|c|c|c|c|c|c|c|c|c|}
\hline \multirow{2}{*}{$\begin{array}{c}\text { Sel } \\
\text { surya }\end{array}$} & \multicolumn{3}{|c|}{ Hari ke-1 } & \multicolumn{3}{|c|}{ Hari ke-2 } & \multicolumn{3}{|c|}{ Hari ke-3 } \\
\hline & $\begin{array}{c}\text { Luxmeter } \\
\text { (lux) }\end{array}$ & $\mathbf{V}(\mathbf{m V})$ & $\mathbf{I}(\boldsymbol{\mu} \mathbf{A})$ & $\begin{array}{c}\text { Luxmeter } \\
\text { (lux) }\end{array}$ & $\mathbf{V}(\mathbf{m V})$ & $\mathbf{I}(\boldsymbol{\mu} \mathbf{A})$ & $\begin{array}{c}\text { Luxmeter } \\
\text { (lux) }\end{array}$ & $\mathbf{V}(\mathbf{m V})$ & $\mathbf{I}(\boldsymbol{\mu} \mathbf{A})$ \\
\hline 1 & 998 & 313 & 0,02 & 900 & 228 & 0,02 & 900 & 322 & 0,02 \\
\hline 2 & 980 & 322 & 0,02 & 900 & 280 & 0,02 & 907 & 270 & 0,02 \\
\hline 3 & 1000 & 326 & 0,02 & 1000 & 343 & 0,02 & 996 & 315 & 0,02 \\
\hline 4 & 990 & 315 & 0,01 & 912 & 323 & 0,02 & 907 & 225 & 0,01 \\
\hline
\end{tabular}

Besarnya arus dan tegangan untuk setiap sel surya berbeda serta mengalami perubahan setiap hari. Faktor penyebabnya antara lain intensitas cahaya yang tidak stabil. Semakin besar intensitas cahaya, arus dan tegangan yang terukur akan semakin besar. Hal ini dikarenakan adanya cahaya (foton) akan membebaskan elektron dan menghasilkan hole. Hole akan disapu ke lapisan $\mathrm{p}$ dan elektron akan di sapu ke lapisan n. Elektron dan hole akan bergabung kembali melalui divais di luar material karena adanya potensial barrier yang menghalangi hole dan elektron berekombinasi melalui sambungan p-n, sehingga besarnya daya (I.V) dapat dihasilkan dari sel di bawah kekuatan pencahayaan. Selain intensitas cahaya terdapat beberapa faktor yaitu, temperatur lingkungan, kondisi lapisan tipis sel surya yang mudah rusak sehingga mempengaruhi kinerja masing-masing sel surya. Arus dan tegangan keluaran dari sel surya yang dirangkai seri dan paralel diukur menggunakan multimeter dengan hasil pengukuran ditunjukkan pada tabel 2 dan tabel 3 .

TABEL 2 Hasil Pengukuran Tegangan Sel Surya Rangkaian Seri

\begin{tabular}{|c|c|c|c|}
\hline \multirow{2}{*}{ Hari ke } & \multicolumn{3}{|c|}{ Rangkaian Seri } \\
\cline { 2 - 4 } & Luxmeter (lux) & $\mathbf{V}(\mathbf{m V})$ & $\mathbf{I}(\boldsymbol{\mu A})$ \\
\hline $\mathbf{1}$ & 1011 & 1272 & 0,02 \\
\hline $\mathbf{2}$ & 980 & 1100 & 0,02 \\
\hline $\mathbf{3}$ & 968 & 1112 & 0,02 \\
\hline
\end{tabular}

TABEL 3 Hasil Pengukuran Tegangan Sel Surya Rangkaian Paralel

\begin{tabular}{|c|c|c|c|}
\hline \multirow{2}{*}{ Hari ke } & \multicolumn{3}{|c|}{ Rangkaian Paralel } \\
\cline { 2 - 4 } & Luxmeter (lux) & $\mathbf{V}(\mathbf{m V})$ & $\mathbf{I}(\boldsymbol{\mu} \mathbf{A})$ \\
\hline $\mathbf{1}$ & 1011 & 1272 & 0,02 \\
\hline $\mathbf{2}$ & 980 & 1100 & 0,02 \\
\hline $\mathbf{3}$ & 968 & 1112 & 0,02 \\
\hline
\end{tabular}

Hasil pengukuran tegangan sel surya yang dirangkai secara seri diperoleh nilai maksimum $1272 \mathrm{mV}$ untuk hari pertama dan nilai minimum $1100 \mathrm{mV}$ untuk hari kedua, sedangkan nilai arus maksimum $0,02 \mu \mathrm{A}$. Hasil pengukuran tegangan sel surya yang dirangkai secara paralel diperoleh nilai maksimum $322 \mathrm{mV}$ untuk hari kedua dan nilai tegangan minimum $313 \mathrm{mV}$ untuk hari pertama, sedangkan nilai arus maksimum $0.08 \mu \mathrm{A}$ untuk hari kedua dan nilai arus minimum $0,07 \mu \mathrm{A}$ untuk hari pertama dan ketiga. 
Hasil pengukuran arus dan tegangan sel surya baik dirangkai seri atau paralel kurang optimal. Hal ini disebabkan faktor sambungan antara sel surya yang belum portable sehingga menyebabkan kerusakan saat dirangkai. Selain faktor tersebut, terdapat penyebab lain yaitu intensitas cahaya yang kurang optimal saat pengambilan data. Intensitas cahaya matahari maksimal yang terukur adalah 1011 lux. Semakin besar intensitas matahari semakin besar arus yang dihasilkan. Cahaya (foton) yang mempunyai energi lebih besar dari energi gap akan mengeksitasi elektron-elektron dari pita valensi ke pita konduksi sehingga akan menghasilkan pasangan elektron dan hole yang lebih banyak dan menghasilkan arus yang lebih besar.

Temperatur berpengaruh terhadap nilai arus dan tegangan yang dihasilkan sel surya. Semakin tinggi temperatur sel surya, daya yang dihasilkan akan semakin rendah. Meningkatnya temperatur sel surya menjadikan lapisan bertambah panas, sehingga elektron dan hole mempunyai energi thermal yang lebih besar dan berlawanan dengan arus dioda yang dibangkitkan dari pencahayaan. Nilai temperatur lingkungan yang terukur saat pengambilan data adalah $26^{\circ} \mathrm{C}$. Selain faktor-faktor di atas terdapat factor yang lain, diantaranya homogenitas lapisan yang berbeda akan mempengaruhi kinerja masing-masing sel surya, rentang waktu setelah pendeposisian sampai pengukuran arus dan tegangan yang cukup lama memungkinkan lapisan tipis bereaksi dengan lingkungan dan menurunkan stabilitas sel surya. Stabilitas sel surya yang kurang baik dapat disebabkan oleh reaksi kimia dengan lingkungan terutama $\mathrm{O} 2$ dan uap air.

\section{KESIMPULAN}

Kurva karakteristik arus dan tegangan (I-V) sel surya lapisan tipis p-n silikon yang dihubungkan secara seri dan paralel menyerupai kurva karakteristik dioda yaitu berbentuk eksponensial. Besarnya arus dan tegangan maksimum dari sel surya yang dihubungkan secara seri adalah $0,02 \mu \mathrm{A}$ dan $1271 \mathrm{mV}$ dan untuk sel surya yang dihubungkan secara paralel $0,08 \mu \mathrm{A}$ dan $322 \mathrm{mV}$.

Nilai Efisiensi dari sel surya pada intensitas matahari maksimum baik dirangkai seri dan paralel mengalami peningkatan dari efisiensi sel surya tunggal. Efisiensi sel surya tunggal adalah $(6,02 \pm 0,27) \%$, nilai efisiensi sel surya yang dirangkai secara seri adalah $(11,929 \pm 0,480)$ $\%$ dan untuk sel surya yang dirangkai secara paralel adalah $(8,737 \pm 0,026) \%$.

\section{REFERENSI}

[1] B. Grew,et. al., Energy Procedia: Advanced Materials and Characterization Techniques for Solar Cells II 60, 14-155 (2014).

[2] Arakelova, E. R., et al. Journal of Contemporary Physics (Armenian Academy of Sciences) 46, 293-299 (2011).

[3] Breitenstein, O., Opto-Electronics Review 21, 259-282 (2013).

[4] He, Yang Yang, et al. Science China Physics, Mechanics and Astronomy 55, 2070-2075 (2012).

[5] Liu, Jing, et al. Applied Physics A 114, 1175-1179 (2014).

[6] Mintairov, M. A., et al. Semiconductors 48, 653-658 (2014).

[7] Pandian, Ramanathaswamy, et al., Applied Physics A 116, 1905-1913 (2014).

[8] Song, Sang-Woo, et al.., Journal of the Korean Physical Society 65, 308-311 (2014).

[9] Andreev, V. M. "Application Of III-V Compounds In Solar Cells." Photovoltaic and Photoactive Materials-Properties, Technology and Applications. Springer Netherlands, 131-156 (2002).

[10] Jacobi, Karl. of Book: Handbook of Thin Film Process Technology. Institute of Physics Publishing, (2001).

[11] Szyszka, B. "Magnetron sputtering of ZnO films." Transparent Conductive Zinc Oxide. Springer Berlin Heidelberg, 187-233 (2008). 